\title{
The Role of Liver Biopsy in Detection of Hepatic Oxidative Stress
}

\author{
Mahmoud Rushdi Abd Ellah \\ Clinical Laboratory Diagnosis, Department of Animal Medicine, Faculty of Veterinary Medicine, Assiut University, \\ Assiut 71526, Egypt \\ Correspondence should be addressed to Mahmoud Rushdi Abd Ellah, mahmoudrushdi@hotmail.com
}

Received 10 December 2010; Revised 30 December 2010; Accepted 7 January 2011

Academic Editor: Cristina Castillo Rodríguez

Copyright (c) 2011 Mahmoud Rushdi Abd Ellah. This is an open access article distributed under the Creative Commons Attribution License, which permits unrestricted use, distribution, and reproduction in any medium, provided the original work is properly cited.

\begin{abstract}
The goal of the current paper is to explore the role of liver biopsy as a tool in detection of hepatic oxidative stress, with brief notes on different types of free radicals, antioxidants, hepatic and blood oxidative stress, and lipid peroxidation. Hepatic oxidative stress was investigated for many years in human and animals, but most of the studies performed in animals were concerned with studying oxidative status in the liver tissues after slaughtering or euthanasia. However, in human medicine, a large number of studies were implemented to investigate the status of antioxidants in liver biopsy specimens. Similar studies are required in animals, as the changes in hepatic antioxidants and formation of lipid peroxide give a good idea about the condition of the liver. On the other hand, hepatic disease may present without significant effect on blood oxidative status, and, consequently, the best way to detect the status of hepatic oxidants and antioxidants is through measuring in liver biopsy. Measuring antioxidants status directly in the liver tissues gives an accurate estimation about the condition of the liver, permits the diagnosis of hepatic dysfunction, and helps to determine the degree of deterioration in the hepatic cells.
\end{abstract}

\section{Introduction}

Free radicals are highly reactive substances produced continuously during metabolic processes. They participate mainly in physiological events such as the immune response, metabolism of unsaturated fatty acids, and inflammatory reaction. The balance between free radicals and antioxidants is disrupted in many diseases. This disruption may be attributed to a number of factors such as the inability of the cells to produce sufficient amounts of antioxidants, the nutritional deficiency of minerals or vitamins, and the excess production of reactive oxygen species [1]. Free radical excess results in impairment of DNA, enzymes, and membranes and induces changes in the activity of the immune system and in the structure of basic biopolymers which, in turn, may be related to mutagenesis and aging processes [2].

The involvement of oxidative stress in the pathogenesis of hepatic dysfunction in human [2-15] and animals [1, 16$25]$ has been investigated for many years. Some of the liver diseases were associated with an increase $[21,24,26]$ or decrease $[17,22,27-29]$ in antioxidant's contents. Usually hepatic antioxidants increase at the beginning of hepatic disease and decrease in severe hepatic injury. The advantages of measuring hepatic oxidative status in liver biopsy are that it helps in diagnosis of hepatic dysfunction, reflects the degree of deterioration in the liver tissues, and helps to determine the severity of hepatic injury, and, also, it aids in recommending antioxidant's therapy in patients that had a hepatic disease with derangement in hepatic antioxidant constituents. The main purpose of the current paper is to explore the value of liver biopsy as a tool for detection of hepatic oxidative stress. A focus was done on different types of free radicals, antioxidants, lipid peroxidation, and hepatic and blood oxidative status in hepatic dysfunction.

\section{Free Radicals}

2.1. Types of Free Radicals. Free radicals can be defined as molecules containing a single unpaired electron in atomic or molecular orbits. These molecules have an important role in the pathogenesis of tissue damage in various disorders [30], such as hepatic dysfunction, mastitis, kidney damage, inflammation, immune injury, and carcinogenesis 
[1]. The most important free radicals include superoxide anion $\left(\mathrm{O}_{2}{ }^{\cdot-}\right)$, hydroxyl radical $\left({ }^{\bullet} \mathrm{OH}\right)$, and hypochlorous acid (HOCL) [31]. HOCL is produced by the reaction of hydrogen peroxide $\left(\mathrm{H}_{2} \mathrm{O}_{2}\right)$ with chloride ions and plays an important role in the leukocyte respiratory burst, which is involved in the host defense system [32]. Nitric oxide $\left(\mathrm{NO}^{\bullet}\right)$ acts as a free radical and as a biological mediator in biochemical reactions. Physiologically it is synthesized from L-arginine by NO synthase employing cofactor NADPH. In the host, $\mathrm{NO}^{\bullet}$ arises in some pathological situations, such as sepsis, stroke, myocardial depression, and inflammatory responses [33].

Superoxide anion induces important reducing reactions in biological materials via Fenton-like reactions, which are catalyzed by redox cycling metal ions, including iron, copper, chromium, and vanadium [34]. These metal ions have the ability to accept and donate single electrons, making them important catalysts of free radical reactions; the most widely distributed and most commonly studied transition metal ions are the cations iron and copper [31]. Superoxide anion reduces $\mathrm{Fe}^{3+}$ in metalloproteins such as ferritin. The reduction of protein bound iron is an important reaction in biological material, because if there is sufficient $\mathrm{H}_{2} \mathrm{O}_{2}$ available, a reaction between the resultant $\mathrm{Fe}^{2+}$ and $\mathrm{H}_{2} \mathrm{O}_{2}$ occurs and gives rise to the highly reactive - $\mathrm{OH}$ [32], and $\mathrm{H}_{2} \mathrm{O}_{2}$ traverses biological membranes and intracellularly targets phospholipids, carbohydrates, metalloproteins, and DNA and causes damage via Fenton's reaction [35].

2.2. Sources of Free Radicals. Free radicals may be released in the liver as a subsequence to hepatic detoxification of drugs, chemicals, and toxic materials [36,37]. The formation of oxygen free radicals may be physiological as in phagocytosis (superoxide and $\mathrm{H}_{2} \mathrm{O}_{2}$ are used by phagocytic cells to kill bacteria), a side effect of metabolic pathways, or may occur in pathological conditions due to toxic agents as in the case of ischemia, inflammation, and disease, or due to decreased antioxidant defenses [38].

Mitochondria are considered a major source for the production of $\mathrm{O}_{2}{ }^{--}$and $\mathrm{H}_{2} \mathrm{O}_{2}$; about 2-3\% of consumed oxygen is constantly converted into reactive oxygen/reactive nitrogen species (ROS/RNS) in the mitochondria; hepatocytes contain many mitochondria and therefore generate excess ROS/RNS [31].

In many liver diseases, including the wide range of neonatal hepatitis, the tissue inflammatory infiltrates are likely to be responsible for the formation of $\mathrm{O}_{2}{ }^{--}, \mathrm{H}_{2} \mathrm{O}_{2}$, $\cdot \mathrm{OH}, \mathrm{HOCL}$, and the highly cytotoxic monochloramine $[39,40]$. In turn, the superoxide anion attracts further neutrophils to the inflammatory site by a chemotactic activity, causing an increase in tissue injury [41]. In addition, activated macrophages, Kupffer cells, and vascular endothelium can generate nitric oxide, which may react with superoxide generating peroxynitrite. The latter is responsible for the inhibition of mitochondrial respiration and DNA synthesis [42].
Liver damage due to iron (hemochromatosis) and copper overload is believed, at least partially, to derive from the catalytic activity of these metals in the Fenton reaction leading to the generation of ROS and increased lipid peroxidation with consequent abnormal mitochondrial function [43-45].

\section{Antioxidants and Free Radicals}

The cells contain a variety of antioxidant mechanisms that play a central role in the protection against reactive oxygen species [46, 47]. The antioxidant system consists of antioxidant enzymes (superoxide dismutase (SOD), catalase and glutathione peroxidase (GSH-Px)), glutathione, ancillary enzymes (glutathione reductase (GR), glutathione S-transferase, and glucose 6-phosphate dehydrogenase $(\mathrm{G} 6 \mathrm{PD})$ ), metal-binding proteins (transferrin, ceruloplasmin, and albumin), vitamins (alpha-tocopherol, ascorbate, and beta-carotene), flavonoids, and urate [48].

Pathological free radical reactions do not necessarily cause cell and tissue damage, as antioxidants of cells and tissues are able to prevent free radical injury [36]. On the intracellular level, ROS formation and metabolism can be summarized as shown in Figure 1.

\section{Hepatic Oxidative Stress and Lipid Peroxidation}

Oxidative stress results when reactive forms of oxygen are produced faster than they can be safely neutralized by antioxidant mechanisms [49] and/or from a decrease in antioxidant defense, which may lead to damage of biological macromolecules and disruption of normal metabolism and physiology [50]. This condition can contribute and/or lead to the onset of health disorders [38] and play a damaging role in a number of liver disorders, for example, in anoxic and reoxygenation injury during transplantation, activated phagocytes and xanthine oxidase formed during ischemia, catalyzing the formation of superoxide during reperfusion $[39,51-53]$.

Lipid peroxidation is implicated in the pathogenesis of several hepatic disorders in human $[2,26]$ and animals $[18$, 22 ]. Hepatic failure in cattle was associated with decreased antioxidant mechanisms inside the cells, which led to the increase in the reactive oxygen species, especially $\mathrm{H}_{2} \mathrm{O}_{2}$. The decrease in hepatic GSH-Px activity in severe fatty degeneration, for example, results in the increase of $\mathrm{H}_{2} \mathrm{O}_{2}$ [22], which can initiate free radical formation through Fenton's reaction. In addition, the decrease in hepatic vitamin $\mathrm{E}$ level, which is an important chain-breaking antioxidant, results in lipid peroxidation and failure to regenerate the ascorbic acid [17, 18]. Increased hepatic oxidative stress was also reported in cows suffering from glycogen degeneration [22], sawdust liver, and liver abscesses [19, 21]. The authors contended that the antioxidant defense was high in the case of sawdust liver, glycogen degeneration, and liver abscess, which indicated that the body can combat the increased free radical stress. 


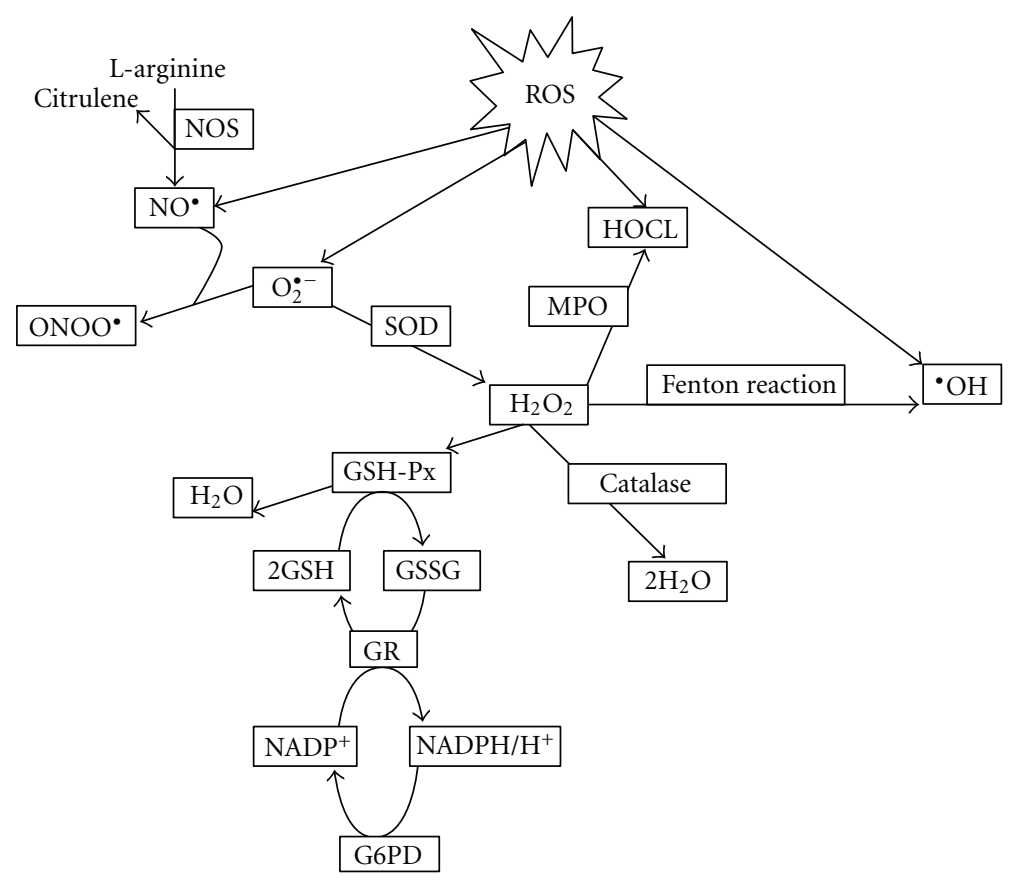

FIGURE 1: Shown are different types of reactive oxygen species (ROS). Abbreviations: GSH-Px: Glutathione peroxidase; HOCl: Hypochlorous acid; $\mathrm{H}_{2} \mathrm{O}_{2}$ : Hydrogen peroxide; MPO: Myeloperoxidase; $\mathrm{NO}^{\bullet}$ : Nitric oxide; NOS: NO synthase; $\mathrm{O}_{2}{ }^{\bullet-}$ : Superoxide anion; ${ }^{\bullet} \mathrm{OH}$ : Hydroxyl radical; $\mathrm{ONOO}^{\bullet}$ : Peroxynitrite anion; SOD: Superoxide dismutase; NADPH: Nicotinamide adenine diphosphate; GSH: Reduced glutathione; GR: Glutathione reductase; G6PD: Glucose-6-phosphate dehydrogenase.

Liver abscesses in fattening steers occur mainly due to intensive feeding of highly concentrated rations. Consumption of a carbohydrate-rich diet stimulates G6PD expression in endothelial and parenchymal cells $[16,19]$. Since G6PD supports reactive oxygen metabolism, the response may represent an antioxidant pathway in the hepatic cell populations that targets sinusoid born reactive oxygen species during infections $[19,21]$.

Underfeeding in cattle was reported to induce changes in the antioxidant systems in liver manifested by lowering hepatic G6PD and SOD activities. This results in depletion of antioxidant defense mechanisms and renders the hepatocytes more susceptible to the lethal effects of endogenous or exogenous peroxides, and it indicates that the generation of lipid peroxides in cattle in poor nutritional condition exceeds the antioxidant capacity of the liver cells, generating a situation of oxidative stress and peroxidation [20].

The leading mechanism of free radical toxicity is the peroxidation of membrane phospholipids, which is initiated by the formation of lipid peroxide or hydroperoxides, and peroxy radicals are formed in the presence of oxygen to start a chain reaction (propagation) $[2,54,55]$. Various pathogenic effects occur as the result of degradation of membrane lipids [31]. Chiefly, the hydroxyl radical and to a lesser extent the superoxide anion leads to peroxidation of membrane lipids thereby causing production of malondialdehyde (MDA) and 4-hydroxyalkenals (4HNE). These substances directly induce hepatocytes damage with generation of proinflammatory cytokines, activation of spindle cells, and fibrogenesis
$[56,57]$ and may bind to various molecules, impairing their functions [5] and therefore lead to membrane damage, protein damage, enzyme dysfunction, and DNA or RNA damage [58]. It is well known that persistent oxidant stress causes mutative effects on cell DNA and increases fibroblastic activity, leading to cirrhosis and carcinoma. Many studies have shown that oxidative stress takes part in the pathogenesis of cholestasis by way of cytokines $[8,11-13]$ and lipid peroxidation [6].

The role of lipid peroxidation in liver fibrosis was assessed. Lipid peroxidation products in the form of MDA adduct were detected in areas of active fibrogenesis. It has been shown that lipid peroxidation products can stimulate fibrogenesis by inducing collagen gene expression, and detection and prevention of lipid peroxidation could be of major interest in preventing fibrosis and cirrhosis in this disease [9].

Increased lipid peroxidation may be caused by inflammation related to viral infection and decreased antioxidant levels. The lipid peroxides formed may be chemotactic for the neutrophils causing increased inflammation, which further drives oxidant-mediated injury in the liver [59]. Previous studies have demonstrated an increase in MDA levels and decrease of the antioxidant capacity in acute and chronic hepatitis $[3,4,55]$. Mitochondrial lipid peroxidation takes place at varying levels in liver disorders independent of etiology $[44,60]$. Increased lipid, protein, and nucleic acid peroxidation in the blood and liver biopsy specimens from patients with chronic hepatitis has been demonstrated $[7,15,26]$. 
TABLE 1: Methods for preparation of liver biopsy implemented in different studies.

\begin{tabular}{|c|c|c|c|c|}
\hline Tissue preparation & Buffer used & Homogenization & $\begin{array}{l}\text { Oxidative } \\
\text { stress } \\
\text { marker } \\
\end{array}$ & Reference \\
\hline \multirow{5}{*}{$\begin{array}{l}\text { Liver biopsy } \\
\text { samples were } \\
\text { washed twice in cold } \\
0.9 \% \text { salt solution }\end{array}$} & Tris-HCL (50 mM) pH 7.5 & $\begin{array}{l}\text { The liver biopsy was homogenized in } 20 \text { volumes of } \\
\text { cold buffer, and then the supernatant was harvested } \\
\text { after centrifugation at } 5000 \mathrm{~g} \text { for } 30 \mathrm{~min} \text { at } 4^{\circ} \mathrm{C} \text {. }\end{array}$ & $\begin{array}{c}\text { SOD, CAT } \\
\text { and GSH }\end{array}$ & {$[24,25]$} \\
\hline & $\begin{array}{l}\text { Chilled potassium chloride } \\
(1.17 \%)\end{array}$ & $\begin{array}{l}\text { Liver biopsy was homogenized in chilled buffer. The } \\
\text { homogenates were centrifuged at } 800 \mathrm{~g} \text { for } 5 \mathrm{~min} \text { at } \\
4^{\circ} \mathrm{C} \text { to separate the nuclear debris. The obtained } \\
\text { supernatant was recentrifuged at } 10,500 \mathrm{~g} \text { for } 20 \mathrm{~min} \\
\text { at } 4^{\circ} \mathrm{C} \text { to get the postmitochondrial supernatant. }\end{array}$ & $\begin{array}{l}\text { SOD, CAT } \\
\text { and MDA }\end{array}$ & [68] \\
\hline & $\begin{array}{l}\text { Ice-cold PBS buffer }(20 \mathrm{mM}) \text {, } \\
\text { pH } 7.3 \text { with } 10 \mathrm{ml} \text { of } 5 \mathrm{mM} \\
\text { butylated hydroxyl toluene }\end{array}$ & $\begin{array}{l}\text { The tissue was homogenized in } 290 \mathrm{ml} \text { ice-cold } \\
\text { buffer. Following this, the suspension was centrifuged } \\
\text { and supernatant was fractioned for analysis. }\end{array}$ & $\begin{array}{l}\text { LPO and } \\
\text { AOP }\end{array}$ & [69] \\
\hline & $\begin{array}{l}\text { Tris- } \mathrm{HCl}(50 \mathrm{mM}), \mathrm{pH} 7.5 \\
5 \mathrm{mM} \text { EDTA, } 1 \mathrm{nM} \\
\text { dithiothreitol }\end{array}$ & $\begin{array}{l}\text { The tissue was homogenized in } 5 \mathrm{ml} / \mathrm{g} \text { cold buffer. } \\
\text { The homogenate was centrifuged at } 10,000 \mathrm{~g} \text { for } 15 \\
\text { minutes at } 4^{\circ} \mathrm{C} \text {. The supernatant was removed for } \\
\text { assay. }\end{array}$ & GSH-Px & {$[70]$} \\
\hline & $\begin{array}{l}\text { Potassium phosphate } \\
(0.05 \mathrm{M}) \text { and } 0.1 \mathrm{mM} \text { EDTA, } \\
\text { pH } 7.8\end{array}$ & $\begin{array}{l}\text { The tissue was homogenized in } 200 \mu \mathrm{L} \text { buffer and } \\
\text { centrifuged at } 15,000 \mathrm{~g} \text { for } 30 \text { minutes at } 4^{\circ} \mathrm{C} \text {. The } \\
\text { supernatant was used for analysis. }\end{array}$ & SOD & {$[70]$} \\
\hline
\end{tabular}

\section{Oxidative Stress and Hepatic Dysfunction: Role of Liver Biopsy}

5.1. Blood and Hepatic Oxidative Stress. Antioxidant status of blood does not reflect hepatic oxidative stress only, but their levels change in response to diseases in other organs. Studying the effect of hepatic dysfunction on blood oxidative status in cows revealed that hepatic glycogen degeneration, fatty degeneration, or liver abscesses had no effect on erythrocytic oxidative status, as indicated by the insignificant changes in erythrocytes GSH-Px and G6PD activities [21, 22]. Many studies had been performed on humans to determine the effect of hepatic dysfunction on erythrocytic oxidative status; some of these studies had reported no significant changes in erythrocytes GSH-Px activity in patients suffered from liver cirrhosis and alcoholic liver disease [61-63]. Other studies had demonstrated that a red cell GSH-Px activity significantly decreased in patients with chronic liver disease [64-66]. In addition, lower activities of erythrocytes GSH$\mathrm{Px}$ and SOD activities have been reported in patients with acute hepatitis B [67]. The cause of such contradictory results may be related to the degree of hepatic dysfunction or the presence or absence of selenium deficiency. Significant decreases in plasma selenium level and erythrocytes GSH-Px had been reported in patients with chronic liver disease [64].

Increased oxidative stress had been reported in the liver of cattle with naturally occurring fatty liver [18, 22], with liver abscessation [21], and in animals on restricted feed intake [20], without significant changes in blood oxidative status; this means that hepatic disease may present without effect on blood oxidative status and also that detection of hepatic oxidative stress is best done through measuring oxidative stress markers in the hepatic tissues by means of liver biopsy.

5.2. Preparation of Liver Biopsy for Antioxidants Measurements. The principles for preparation of liver biopsy are that liver biopsy must be prepared directly after collection, otherwise stored at $-80^{\circ} \mathrm{C}$, liver biopsy must be washed twice in a cold saline or cold buffer before homogenization, blot dry, and then homogenized in a cold buffer at certain $\mathrm{pH}$. After centrifugation, the supernatant is harvested and used to measure hepatic antioxidant enzyme activities, which can be performed using commercial test kits (Table 1).

5.3. Liver Biopsy and Oxidative Stress. Oxygen free radicals might play a role in the pathogenesis of tissue damage in many pathological conditions and have been implicated in a variety of liver diseases. It, therefore, may participate in the pathogenesis of toxic liver diseases and other hepatic alterations [10]. Oxidative stress is a major pathogenetic event occurring in several liver disorders ranging from metabolic to proliferated ones and is a main cause of liver damage in ischemia/reperfusion during liver transplantation [14].

The involvement of oxidative stress in the pathogenesis of liver injury has been investigated for many years [2-4]. Some of these studies were conducted using liver biopsy in human [70, 71] and animals [24, 25]. But most of the studies in animals measured hepatic oxidative stress after slaughtering or euthanasia. Examples include measuring hepatic G6PD activity in chemically induced hepatocellular carcinoma in rat liver [72] and in liver of rat with macronodular cirrhosis induced by long-term thioacetamide administration [73]. In cattle, hepatic GSH-Px activity [22] 
and vitamin $\mathrm{E}[17,18]$ were measured in cows suffering from severe fatty degeneration. In addition, hepatic GSH-Px and G6PD activities were determined in cows suffering from glycogen degeneration [22], sawdust liver, and liver abscesses $[16,19,21]$. Furthermore, hepatic G6PD and SOD activities were measured in cows with restricted feed intake [20].

Recently, liver biopsy was applied as a tool for detecting hepatic oxidative stress in cattle from the viewpoint of the status of hepatic antioxidant enzymes after injection of a potent hepatotoxic (DL-ethionine), data published in $[24,25]$; the supernatant of liver homogenate was used to measure hepatic SOD, catalase [25], total glutathione level and glutathione reductase activity [24].

Many studies were performed to establish the importance of liver biopsy from the viewpoint of oxidative stress in a variety of liver disorders in human. Examples in human include the following oxidative stress-related parameters were investigated in liver biopsy from NAFLD patients and used to assay activities of CAT and GSH-Px [28]. Oxidative stress status in children with glycogen storage disease [74] and with cholestatic chronic liver disease [70] was investigated by measuring GSH-Px, SOD, and CAT activities in liver biopsy samples. Activities of SOD, CAT, and GSH-Px were measured in liver biopsy specimens from patients with various liver diseases, including chronic persistent hepatitis, chronic active hepatitis, nonalcoholic cirrhosis, alcoholic cirrhosis, and acute hepatitis [71].

Increased hepatic oxidative stress had also been detected in liver biopsy from patients with cirrhosis and hepatocellular carcinoma, shown by the decrease of GSH-Px activity, hepatic and blood glutathione (GSH) levels, along with an increase in the oxidized glutathione/glutathione ratio in cirrhotic [26, 27] and liver cancer tissues [29], which reflects a decrease in both the synthesize capacity of liver and the antioxidant defense.

It is clear from the above review of the literature that liver biopsy can be used for measuring oxidative status of the liver tissues and that significant changes were detected in different hepatic dysfunctions. Antioxidant activities in liver biopsy can be used to diagnose liver disease and as a prognostic factor for the liver disease under investigation.

\section{Conclusion}

Most of the studies done in animals were concerned with studying the hepatic oxidative stress after slaughtering or euthanasia. Studying the hepatic oxidative status in liver biopsy is lacking in animals. In human medicine, a large number of studies were implemented to achieve this goal. Hepatic disease may present without significant effect on blood oxidative status. Consequently, the best way is to measure hepatic oxidants and antioxidants in liver biopsy, which reflects the actual status of the liver.

\section{Abbreviations}

4HNE: 4-hydroxyalkenals

AOP: Antioxidant potential

CAT: Catalase
EDTA: Ethylenediaminetetraacetic acid

G6PD: Glucose-6-phosphate dehydrogenase

GSH-Px: Glutathione peroxidase

GR: Glutathione reductase

$\mathrm{H}_{2} \mathrm{O}_{2}$ : Hydrogen peroxide

-OH: Hydroxyl radical

HOCl: Hypochlorous acid

MDA: Malondialdehyde

MPO: Myeloperoxidase

NADPH: Nicotinamide adenine diphosphate

NO : $\quad$ Nitric oxide

NOS: $\quad$ NO synthase

NAFLD: Nonalcoholic fatty liver disease

$\mathrm{ONOO}^{\bullet}$ : Peroxynitrite anion

ROS/RNS: Reactive oxygen/reactive nitrogen species

GSH: $\quad$ Reduced glutathione

$\mathrm{O}_{2}{ }^{\bullet-}$ : $\quad$ Superoxide anion

SOD: $\quad$ Superoxide dismutase

LPO: Total lipid peroxide.

\section{References}

[1] M. R. Abd Ellah, "Involvement of free radicals in animal diseases," Comparative Clinical Pathology, vol. 19, no. 6, pp. 615-619, 2010.

[2] G. Poli, "Liver damage due to free radicals," British Medical Bulletin, vol. 49, no. 3, pp. 604-620, 1993.

[3] M. Comporti, "Lipid peroxidation and cellular damage in toxic liver injury," Laboratory Investigation, vol. 53, no. 6, pp. 599-623, 1985.

[4] G. Poli, E. Albano, and M. U. Dianzani, "The role of lipid peroxidation in liver damage," Chemistry and Physics of Lipids, vol. 45, no. 2-4, pp. 117-142, 1987.

[5] M. Zern, M. Czaja, and F. Weiner, "The use of molecular hybridization techniques as tools to evaluate hepatic fibrogenesis," in Connective Tissue in Health and Disease, M. Rojkind, Ed., pp. 99-122, Boca Raton, Fla, USA, CRC Press, 1990.

[6] L. Y. Tsai, K. T. Lee, S. M. Tsai, S. C. Lee, and H. S. Yu, "Changes of lipid peroxide levels in blood and liver tissue of patients with obstructive jaundice," Clinica Chimica Acta, vol. 215, no. 1, pp. 41-50, 1993.

[7] N. De Maria, A. Colantoni, S. Fagiuoli et al., "Association between reactive oxygen species and disease activity in chronic hepatitis C," Free Radical Biology and Medicine, vol. 21, no. 3, pp. 291-295, 1996.

[8] J. A. Gonzalez-Correa, J. P. De La Cruz, E. Martin-Aurioles, M. A. Lopez-Egea, P. Ortiz, and F. Sanchez De La Cuesta, "Effects of S-adenosyl-L-methionine on hepatic and renal oxidative stress in an experimental model of acute biliary obstruction in rats," Hepatology, vol. 26, no. 1, pp. 121-127, 1997.

[9] V. Paradis, P. Mathurin, M. Kollinger et al., "In situ detection of lipid peroxidation in chronic hepatitis C: correlation with pathological features," Journal of Clinical Pathology, vol. 50, no. 5, pp. 401-406, 1997.

[10] J. Fehér, G. Lengyel, and A. Blázovics, "Oxidative stress in the liver and biliary tract diseases," Scandinavian Journal of Gastroenterology, vol. 228, pp. 38-46, 1998.

[11] J. L. Wallace and M. J. S. Miller, "Nitric oxide in mucosal defense: a little goes a long way," Gastroenterology, vol. 119, no. 2, pp. 512-520, 2000. 
[12] C. Spiral, M. H. Nathanson, R. Fiorotto et al., "Proinflammatory cytokines inhibit secretion in rat bile duct epithelium," Gastroenterology, vol. 121, no. 1, pp. 156-169, 2001.

[13] G. Alpini, J. M. McGill, and N. F. LaRusso, "The pathobiology of biliary epithelia,” Hepatology, vol. 35, no. 5, pp. 1256-1268, 2002.

[14] L. Cesaratto, C. Vascotto, S. Calligaris, and G. Tell, "The importance of redox state in liver damage," Annals of Нераtology, vol. 3, no. 3, pp. 86-92, 2004.

[15] E. Jabłonowska, H. Tchórzewski, P. Lewkowicz, and J. Kuydowicz, "Reactive oxygen intermediates and serum antioxidative system in patients with chronic $\mathrm{C}$ hepatitis treated with IFN- $\alpha$ and thymus factor X," Archivum Immunologiae et Therapiae Experimentalis, vol. 53, no. 6, pp. 529-533, 2005.

[16] A. A. Khan, D. Lovejoy, A. K. Sharma, R. M. Sharma, M. G. Prior, and L. E. Lillie, "Effects of high dietary sulphur on enzyme activities, selenium concentrations and body weights of cattle," Canadian Journal of Veterinary Research, vol. 51, no. 2, pp. 174-180, 1987.

[17] P. Mudron, J. Rehage, H. P. Sallmann, M. Mertens, H. Scholz, and G. Kovac, "Plasma and liver alpha-tocopherol in dairy cows with left abomasal displacement and fatty liver," Zentralblatt für Veterinärmedizin. Reihe A, vol. 44, no. 2, pp. 91-97, 1997.

[18] P. Mudron, J. Rehage, K. Qualmann, H. P. Sallmann, and H. Scholz, "A study of lipid peroxidation and vitamin E in dairy cows with hepatic insufficiency," Zentralblatt für Veterinärmedizin. Reihe A, vol. 46, no. 4, pp. 219-224, 1999.

[19] Z. Spolarics, "A carbohydrate-rich diet stimulates glucose6-phosphate dehydrogenase expression in hepatic sinusoidal endothelial cells," Journal of Nutrition, vol. 129, no. 1, pp. 103 $108,1999$.

[20] A. Sansinanea, S. Cerone, G. Virkel, S. Streitenberger, M. Garcia, and N. Auza, "Nutritional condition affects the hepatic antioxidant systems in steers," Veterinary Research Communications, vol. 24, no. 8, pp. 517-525, 2000.

[21] M. R. Abd Ellah, K. Nishimori, M. Goryo, K. Okada, and J. Yasuda, "Glucose 6-phosphate dehydrogenase and glutathione peroxidase activities in hepatic abscesses of cattle," Veterinary Biochemistry, vol. 39, no. 2, pp. 25-30, 2002.

[22] M. R. Abd Ellah, K. Nishimori, M. Goryo, K. Okada, and J. Yasuda, "Glutathione peroxidase and glucose6-phosphate dehydrogenase activities in bovine blood and liver," Journal of Veterinary Medical Science, vol. 66, no. 10, pp. 1219-1221, 2004.

[23] M. R. Abd Ellah, M. Goryo, K. Okada, and J. Yasuda, "Glutathione peroxidase and glucose6-phosphate dehydrogenase activities in bovine blood and liver," Journal of Veterinary Medical Science, vol. 66, no. 10, pp. 1219-1221, 2004.

[24] M. R. Abd Ellah, K. Okada, M. Goryo, S. Kobayashi, A. Oishi, and J. Yasuda, "Total glutathione and glutathione reductase in bovine erythrocytes and liver biopsy," Journal of Veterinary Medical Science, vol. 70, no. 8, pp. 861-864, 2008.

[25] M. R. Abd Ellah, K. Okada, M. Goryo, A. Oishi, and J. Yasuda, "Superoxide dismutase activity as a measure of hepatic oxidative stress in cattle following ethionine administration," Veterinary Journal, vol. 182, no. 2, pp. 336-341, 2009.

[26] F. Farinati, R. Cardin, N. De Maria et al., "Iron storage, lipid peroxidation and glutathione turnover in chronic antiHCV positive hepatitis," Journal of Hepatology, vol. 22, no. 4, pp. 449-456, 1995.
[27] G. Barbaro, G. D. Lorenzo, M. Ribersani et al., "Serum ferritin and hepatic glutathione concentrations in chronic hepatitis $\mathrm{C}$ patients related to the hepatitis $\mathrm{C}$ virus genotype," Journal of Hepatology, vol. 30, no. 5, pp. 774-782, 1999.

[28] L. A. Videla, R. Rodrigo, M. Orellana et al., "Oxidative stressrelated parameters in the liver of non-alcoholic fatty liver disease patients," Clinical Science, vol. 106, no. 3, pp. 261-268, 2004.

[29] H. Czeczot, D. Ścibior, M. Skrzycki, and M. Podsiad, "Glutathione and GSH-dependent enzymes in patients with liver cirrhosis and hepatocellular carcinoma," Acta Biochimica Polonica, vol. 53, no. 1, pp. 237-241, 2006.

[30] B. Dalgiç, N. Sönmez, G. Biberoğlu, A. Hasanoğlu, and D. Erbaş, "Evaluation of oxidant stress in Wilson's disease and non-Wilsonian chronic liver disease in childhood," Turkish Journal of Gastroenterology, vol. 16, no. 1, pp. 7-11, 2005.

[31] S. J. Stohs, "The role of free radicals in toxicity and disease," Journal of Basic and Clinical Physiology and Pharmacology, vol. 6, no. 3-4, pp. 205-228, 1995.

[32] J. Lunec, "Free radicals: their involvement in disease processes," Annals of Clinical Biochemistry, vol. 27, no. 3, pp. 173182, 1990.

[33] D. S. Bredt and S. H. Snyder, "Nitric oxide: a physiological messenger molecule," Annual Review of Biochemistry, vol. 63, pp. 175-195, 1994.

[34] S. J. Stohs and D. Bagchi, "Oxidative mechanisms in the toxicity of metal ions," Free Radical Biology and Medicine, vol. 18, no. 2, pp. 321-336, 1995.

[35] A. Samuni, M. Chevion, and G. Czapski, "Unusual copperinduced sensitization of the biological damage due to superoxide radicals," Journal of Biological Chemistry, vol. 256, no. 24, pp. 12632-12635, 1981.

[36] J. Feher, A. Vereckei, and G. Lengyel, "Role of free-radical reactions in liver diseases," Acta Physiologica Hungarica, vol. 80, no. 1-4, pp. 351-361, 1992.

[37] T. Ogino and S. Okada, "Oxidative damage of bovine serum albumin and other enzyme proteins by iron-chelate complexes," Biochimica et Biophysica Acta, vol. 1245, no. 3, pp. 359-365, 1995.

[38] J. K. Miller, E. Brzezinska-Slebodzinska, and F. C. Madsen, "Oxidative stress, antioxidants, and animal function," Journal of Dairy Science, vol. 76, no. 9, pp. 2812-2823, 1993.

[39] P. A. Southorn and G. Powis, "Free radicals in medicine. II. Involvement in human disease," Mayo Clinic Proceedings, vol. 63, no. 4, pp. 390-408, 1988.

[40] J. M. McCord, "Oxygen-derived free radicals," New Horizons, vol. 1, no. 1, pp. 70-76, 1993.

[41] W. F. Petrone, D. K. English, K. Wong, and J. M. McCord, "Free radicals and inflammation: superoxide-dependent activation of a neutrophil chemotactic factor in plasma," Proceedings of the National Academy of Sciences of the United States of America, vol. 77, no. 2, pp. 1159-1163, 1980.

[42] S. Moncada and A. Higgs, "The L-arginine-nitric oxide pathway," New England Journal of Medicine, vol. 329, no. 27, pp. 2002-2012, 1993.

[43] R. J. Sokol, M. W. Devereaux, K. O’Brien, R. A. Khandwala, and J. P. Loehr, "Abnormal hepatic mitochondrial respiration and cytochrome $\mathrm{C}$ oxidase activity in rats with long-term copper overload," Gastroenterology, vol. 105, no. 1, pp. 178187, 1993.

[44] R. J. Sokol, D. Twedt, J. M. McKim et al., "Oxidant injury to hepatic mitochondria in patients with Wilson's disease and Bedlington terriers with copper toxicosis," Gastroenterology, vol. 107, no. 6, pp. 1788-1798, 1994. 
[45] B. R. Bacon, R. O’Neill, and R. S. Britton, "Hepatic mitochondrial energy production in rats with chronic iron overload," Gastroenterology, vol. 105, no. 4, pp. 1134-1140, 1993.

[46] A. Par and T. Javor, "Alternatives in hepatoprotection: cytoprotection-influences on mono-oxidase system-free radical scavengers. (A review)," Acta Physiologica Hungarica, vol. 64, no. 3-4, pp. 409-423, 1984.

[47] B. Halliwell, "Reactive oxygen species in living systems: source, biochemistry and role in human disease," American Journal of Medicine, vol. 91, p. 1422, 1991.

[48] B. Halliwell, "Free radicals, antioxidants, and human disease: curiosity, cause, or consequence?" Lancet, vol. 344, no. 8924, pp. 721-724, 1994.

[49] H. Sies, Oxidative Stress: Oxidants and Antioxidants, Academic Press, London, UK, 1991.

[50] M. Trevisan, R. Browne, M. Ram et al., "Correlates of markers of oxidative status in the general population," American Journal of Epidemiology, vol. 154, no. 4, pp. 348-356, 2001.

[51] R. J. Nauta, E. Tsimoyiannis, M. Uribe, D. B. Walsh, D. Miller, and A. Butterfield, "Oxygen-derived free radicals in hepatic ischemia and reperfusion injury in the rat," Surgery Gynecology and Obstetrics, vol. 171, no. 2, pp. 120-125, 1990.

[52] C. A. Brass, J. Narciso, and J. L. Gollan, "Enhanced activity of the free radical producing enzyme xanthine oxidase in hypoxic rat liver," Journal of Clinical Investigation, vol. 87, no. 2, pp. 424-431, 1991.

[53] B. G. Rosser and G. J. Gores, "Liver cell necrosis: cellular mechanisms and clinical implications," Gastroenterology, vol. 108, no. 1, pp. 252-275, 1995.

[54] M. J.P. Arthur, I. S. Bentley, and A. R. Tanner, "Oxygenderived free radicals promote hepatic injury in the rat," Gastroenterology, vol. 89, no. 5, pp. 1114-1122, 1985.

[55] G. Bianchi, G. Marchesini, A. Fabbri, M. Ronchi, R. Chianese, and G. Grossi, "Lipoperoxide plasma levels in patients with liver cirrhosis," Hepatogastroenterology, vol. 44, no. 15, pp. 784-788, 1997.

[56] D. Pessayre, A. Berson, B. Fromenty, and A. Mansouri, "Mitochondria in steatohepatitis," Seminars in Liver Disease, vol. 21, no. 1, pp. 57-69, 2001.

[57] Z. M. Younossi, A. M. Diehl, and J. P. Ong, "Nonalcoholic fatty liver disease: an agenda for clinical research," Hepatology, vol. 35, no. 4, pp. 746-752, 2002.

[58] P. Vajdovich, "Measurements of oxidative stress," Veterinary Clinical Pathology, vol. 30, p. 158, 2001.

[59] J. Deutsch, "G6PD assay," in Methods in Enzymatic Analysis, H. U. Bergmeyer, Ed., vol. 3, p. 190, Academic Press, New York, NY, USA, 1983.

[60] A. Mansouri, I. Gaou, B. Fromenty et al., "Premature oxidative aging of hepatic mitochondrial DNA in Wilson's disease," Gastroenterology, vol. 113, no. 2, pp. 599-605, 1997.

[61] I. Akkuş, F. Gültekin, M. Aköz et al., "Effect of moderate alcohol intake on lipid peroxidation in plasma, erythrocyte and leukocyte and on some antioxidant enzymes," Clinica Chimica Acta, vol. 266, no. 2, pp. 141-147, 1997.

[62] U. Johansson, F. Johnsson, and B. Joelsson, "Selenium status in patients with liver cirrhosis and alcoholism," British Journal of Nutrition, vol. 55, no. 2, pp. 227-233, 1986.

[63] A. R. Tanner, I. Bantock, and L. Hinks, "Depressed selenium and vitamin E levels in an alcoholic population. Possible relationship to hepatic injury through increased lipid peroxidation," Digestive Diseases and Sciences, vol. 31, no. 12, pp. 1307-1312, 1986.
[64] J. Czuczejko, B. A. Zachara, E. Staubach-Topczewska, W. Halota, and J. Kedziora, "Selenium, glutathione and glutathione peroxidases in blood of patients with chronic liver diseases," Acta Biochimica Polonica, vol. 50, no. 4, pp. 11471154, 2003.

[65] M. H. Yasa, M. Kacmaz, H. S. Ozturk, and I. Durak, "Antioxidant status of erythrocytes from patients with cirrhosis," Hepatogastroenterology, vol. 46, no. 28, pp. 2460-2463, 1999.

[66] A. M. Chrobot, A. Szaflarska-Szczepanik, and G. Drewa, "Antioxidant defense in children with chronic viral hepatitis B and C," Medical Science Monitor, vol. 6, no. 4, pp. 713-718, 2000.

[67] S. G. Pak and E. V. Nikitin, "Status of the processes of free radical oxidation and antioxidation system in patients with a severe course of hepatitis B," Klinicheskaya Meditsina, vol. 69, no. 9, pp. 54-57, 1991.

[68] S. Noori, N. Arendt, M. Qureshi, and T. Mahboob, "Reduction of carbon tetrachloride-induced rat liver injury by coffee and green tea," Pakistan Journal of Nutrition, vol. 8, no. 4, pp. 452458, 2009.

[69] J. Madill, B. M. Arendt, E. Aghdassi et al., "Hepatic lipid peroxidation and antioxidant micronutrients in HCV liver transplant patients with and without disease recurrence," Transplantation Proceedings, vol. 41, no. 9, pp. 3800-3805, 2009.

[70] N. A. Ismail, S. H. Okasha, A. Dhawan, A. O. Abdel-Rahman, O. G. Shaker, and N. A. Sadik, "Antioxidant enzyme activities in hepatic tissue from children with chronic cholestatic liver disease," Saudi Journal of Gastroenterology, vol. 16, no. 2, pp. 90-94, 2010.

[71] H. Togashi, H. Shinzawa, H. Wakabayashi et al., "Activities of free oxygen radical scavenger enzymes in human liver," Journal of Hepatology, vol. 11, no. 2, pp. 200-205, 1990.

[72] J. S. S. G. De Jong, W. M. Frederiks, and C. J. F. Van Noorden, "Oxygen insensitivity of the histochemical assay of glucose-6-phosphate dehydrogenase activity for the detection of (pre)neoplasm in rat liver," Journal of Histochemistry and Cytochemistry, vol. 49, no. 5, pp. 565-571, 2001.

[73] N. Sanz, C. Díez-Fernández, A. M. Valverde, M. Lorenzo, M. Benito, and M. Cascales, "Malic enzyme and glucose 6phosphate dehydrogenase gene expression increases in rat liver cirrhogenesis," British Journal of Cancer, vol. 75, no. 4, pp. 487-492, 1997.

[74] N. A. Ismail, S. H. Okasha, A. Dhawan, A. M. O. Abdel Rahman, O. G. Shaker, and N. A. H. Sadik, "Glutathione peroxidase, superoxide dismutase and catalase activities in hepatic tissue from children with glycogen storage disease," Archives of Medical Science, vol. 5, no. 1, pp. 86-90, 2009. 

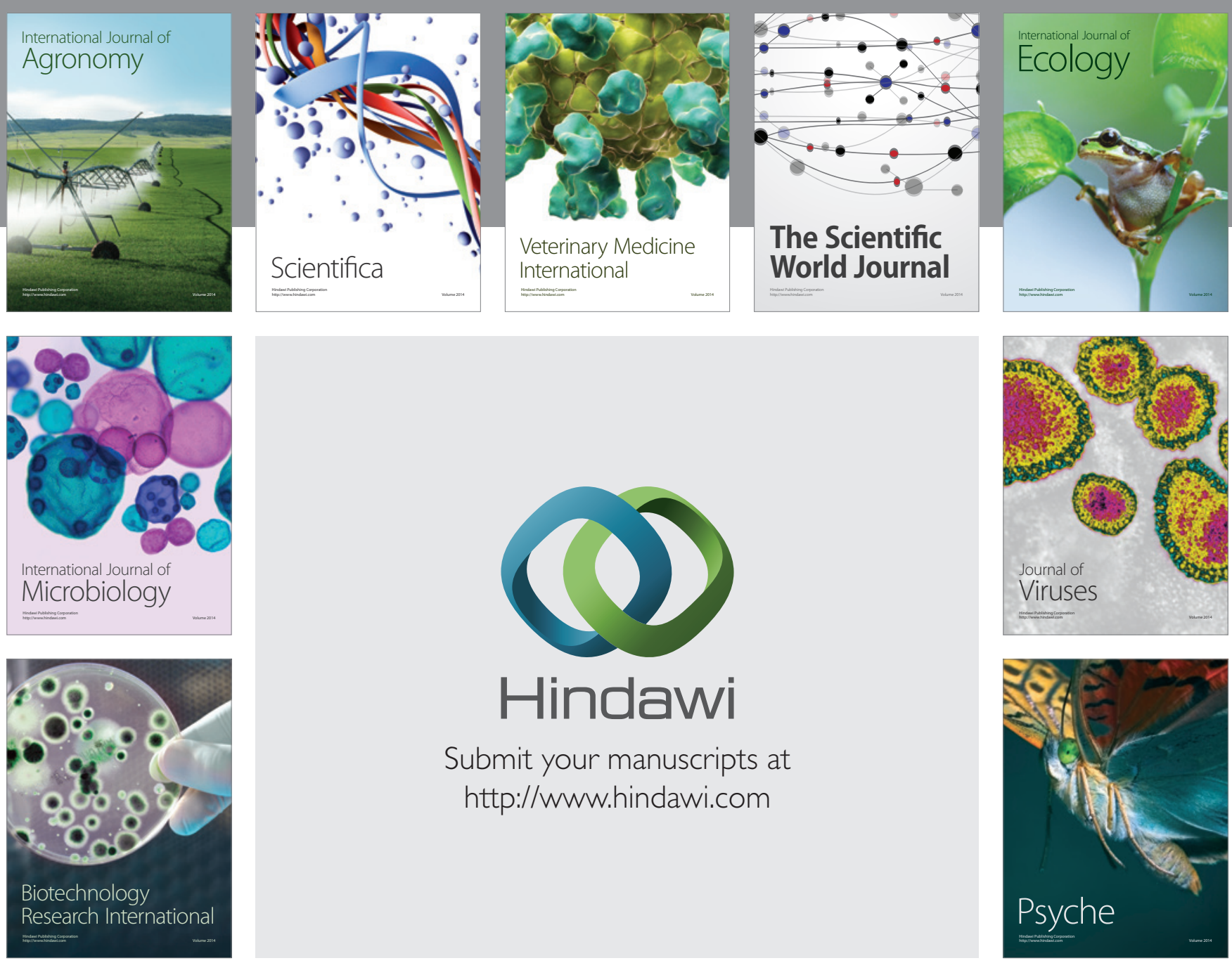

Submit your manuscripts at

http://www.hindawi.com
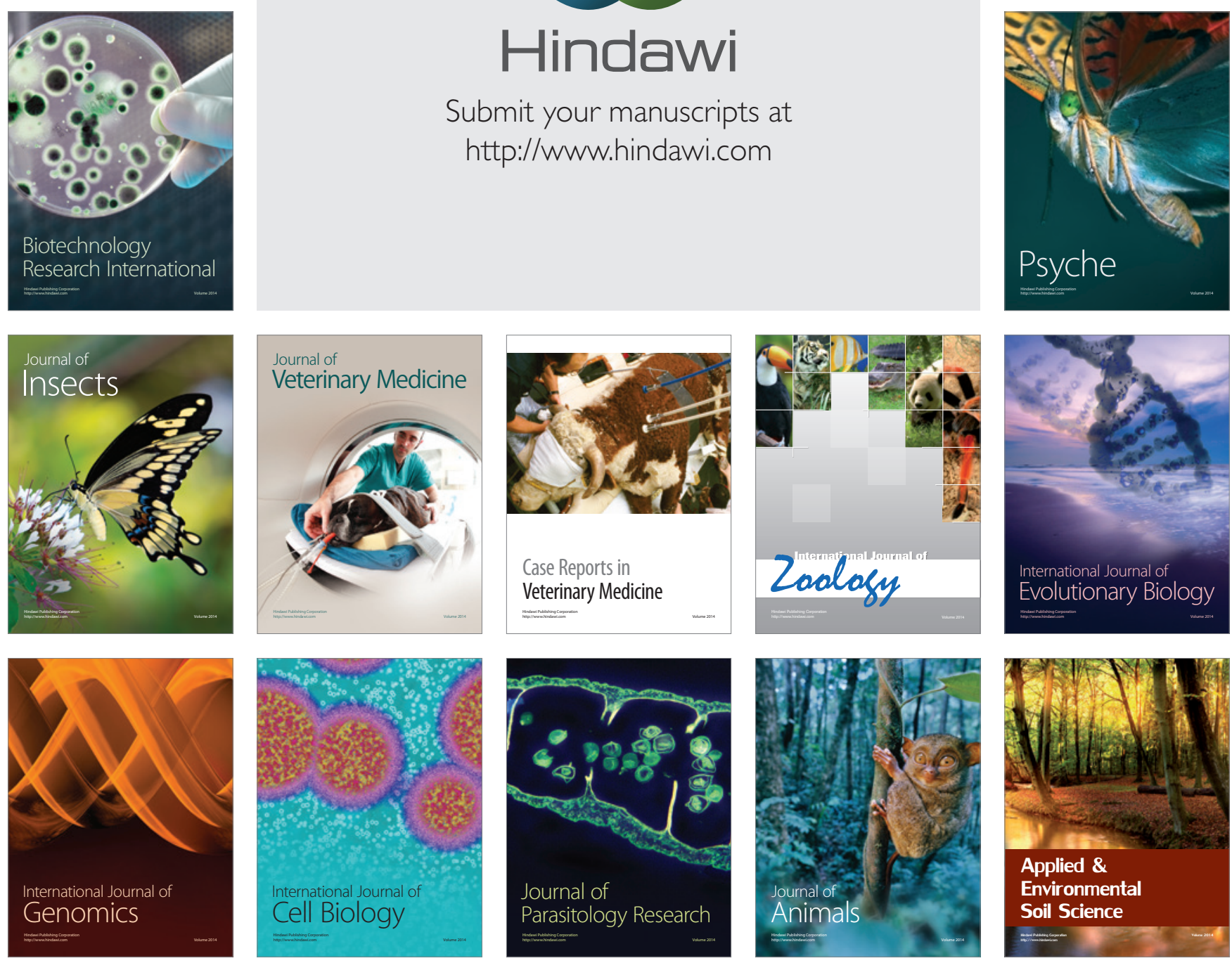